\title{
PAINTERS WITH A CAMERA (I968/69): IN SEARCH OF AN INDIAN PHOTOGRAPHY EXHIBITION
}

\section{Diva Gujral}

copy of the exhibition pamphlet for the show Painters with a Camera
(I968, figures I, 2), held at Jehangir Art Gallery in Bombay (now
Mumbai), presents a little-known excursion into the history of experimental photography in India. The exhibition consisted of seven artists - Jyoti Bhatt, Feroz Katpitia, Narendra Mehta, Jeram Patel, Vinodray Patel, Vinod S Patel, and Gulamohammed Sheikh - each of whom were teachers at the Faculty of Fine Arts, Maharaja Sayajirao University in Baroda (today Vadodara) in the western state of Gujarat, the first art school established in independent India. All, with the exception of Narendra Mehta, were young faculty-members; Mehta was a former professor to a number of his fellow exhibitioners. Although only coming together for this particular exhibition, the individual artists had by now developed some amount of fame: Jyoti Bhatt, who was presented with the national award for painting in I956, had already had paintings and intaglio prints accepted by the MoMA and the National Gallery of Modern Art in New Delhi; Jeram Patel's famed compositions, made with blowtorches on wood, as well as his quieter ink on paper compositions, had been shown widely in London; and Feroz Katpitia (although he would subsequently fall out of currency) is perhaps best known for his mural at Parliament House, New Delhi, completed in the I950s. A shared interest in printmaking that united a number of the exhibition's constituent practices, most notably Jyoti Bhatt and Vinod S Patel and Narendra Mehta, is alluded to in its title image, a fragmented portrait of Vinodray Patel made by Vinod S Patel. Reduced to a bare network of black and white silhouettes, an elementary outline of Vinodray's face is steadily deconstructed and reconstituted across the course of the image. The faces are rendered beyond recognition, mapped out in differing swathes of positive and negative space that alternately spill into the inky black background or stand out against it. 


\section{VINOD S. PATEL}

Born 1938,

Studied Applied Arts at

Faculty of Fine Arts, Baroda;

Central School of Arts \& Crafts

London. U. K.

Teaching Graphics at Faculty of

Fine Arts, M. S. University.

\section{GULAM SHEIKH}

Born 19j7, Surendranagar

(Saurashtra )

Studied Painting at :

Faculty of Fine Arts, Baroda;

Royal College of Arts, London

U. K.

Paintings are in private and public collections.

Teaching at. Faculty of Fine Arts,

M. S. University of Baroda.

\section{NARENDRA MEHTA}

Studied painting and graphics at Kalabhavan, Baroda, Shantiniketan, 1931

Sir J. J. School of Arts 1932-36 Free Lancing : 1936 to 1949. Teaching Graphics since 1949 at Faculty of Fine Arts.

M. S. University Baroda.

\section{JERAM PATEL}

Born 1930. studied drawing and painting at Sir J. J. School of Arts, Bombay. Received the national diploma in design in 1959 from the Central School of Arts and Crafts. London. One man shows 1959-London. 1960-62-63-63-65 and 68 New Delhi 1966 Calcutta. National awards 1957-1963. Represented at the Tokyo Biennale, Sao, Paulo Biennale and at the first indian triennale. Paintings and Graphics are in private and public collections including national gallery of modern art New Delhi. Works included in the travelling exhibition to ten museums in the United States. Works included in the "Art now in India" London Newcastle and Ghent 1965. Member Lalitkala Akademi. New Delhi. At present working as a reader at Faculty of Fine Arts, Baroda.

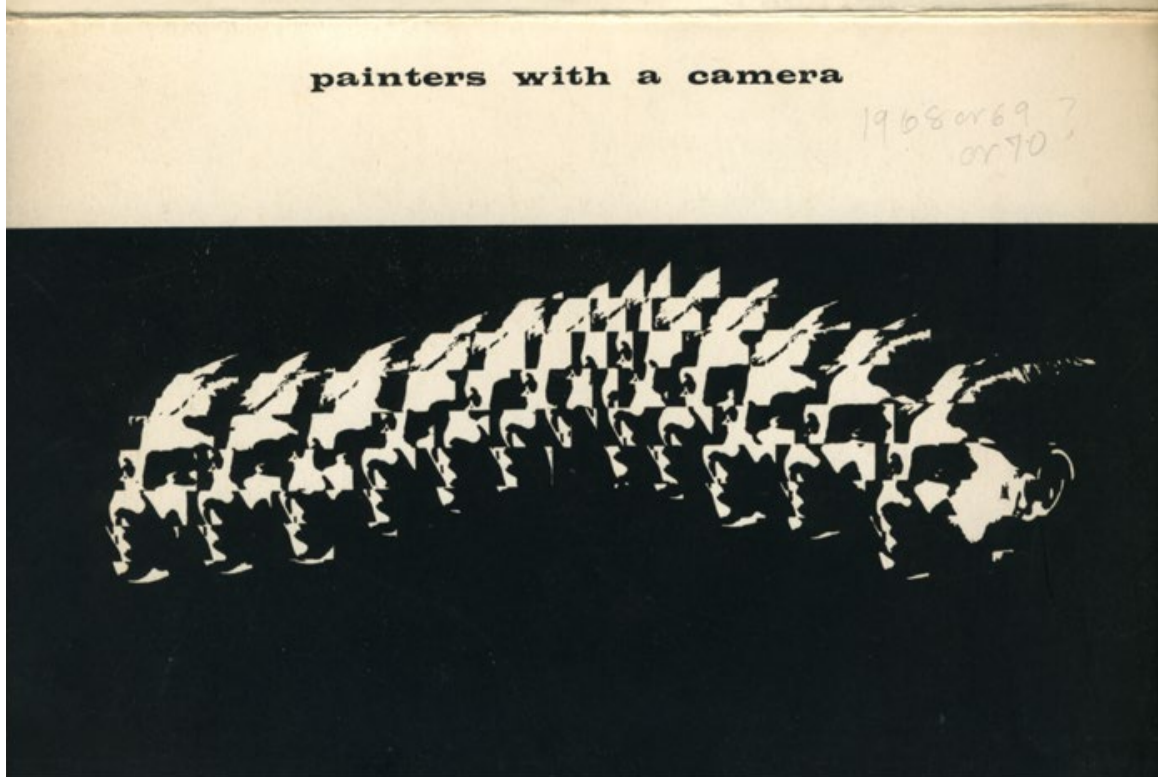

Figure I Pamphlet for Painters with a Camera, I968, part I. Jyoti Bhatt archive. Courtesy of Jyoti Bhatt and Asia Art Archive. 


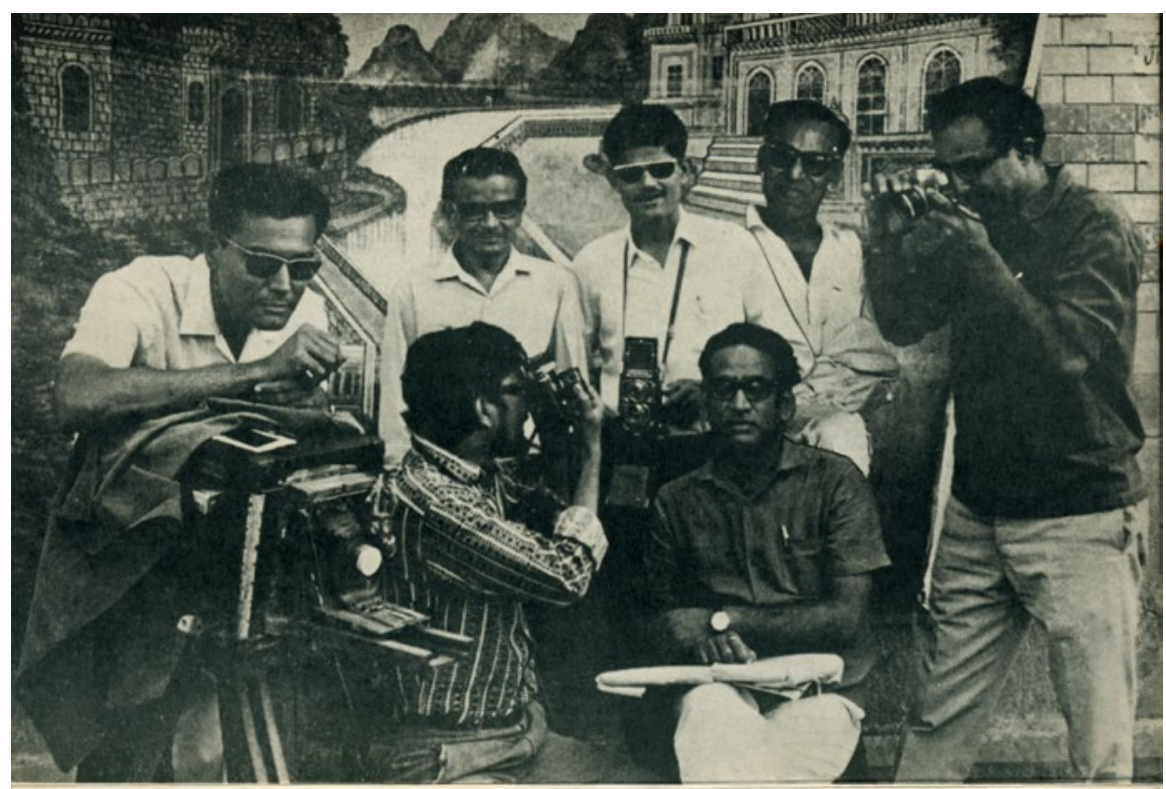

STANDING FROM L. JYOTI BHATT, VINODRAY PATEL, VINOD S, PATEL. NARENDRA MEHTA, FEROZ KATPITIA. SEATED FROM L. GULAM SHEIKH, JERAM PATEL.

\section{VINODRAY PATEL}

Born 1933. Joined Fine Arts College Baroda - 1955. M. A. (fine) Painting 1961. Held one man show in Bombay 1963. National Award 1961 and prizes in various art Exhibitions. Participated in various exhibitions abroad.

Paintings in private collections in India \& abroad.

\section{JYOTI BHATT}

Born 1934, Bhavnagar

(Saurashtra)

Studied painting and print making at :

Faculty of Fine Arts, Baroda;

Akademia Di Belle Arti,

Naples, Italy;

Pratt Institute and Pratt Graphic Art Center, New York, U.S.A. Paintings and graphics are is: private and public collections including National Gallary of Modern Art (New Delhi) and Museum of Modern Art, New York. Teaching Painting at Faculty of Fine Arts, M. S. University of Baroda.

\section{FEROZ KATPITIA}

Born at Baroda. Joined Faculty of Fine Arts, Baroda in 1950. M. A. (Fine) Degree in 1956.

Exhibited his paintings in various All India exhibitions. Executed a mural for Parliament House, New Delhi-Since 1957 on the staff of Faculty of Fine Arts, Baroda.

Figure 2 Pamphlet for Painters with a Camera, I968, part II. Jyoti Bhatt archive. Courtesy of Jyoti Bhatt and Asia Art Archive. 
The copy of the pamphlet scanned from the archive of Jyoti Bhatt bears a faint inscription: 'I968 or 69? Or 70 ?' ${ }^{1}$ Although fleeting mentions of the exhibition flicker across publications concerning the seven artists who mounted the exhibition, the details of Painters with a Camera have been obscured in contradictory accounts. Whereas Gulammohammed Sheikh's writing about the show dates it to I969, leading other scholars of modern Indian art to follow in his example, a lone scan of the invitation card sent out to visitors notes 8 November I968 (I968, figure 3) as the opening day. Even less is known about the contents of the exhibition - no installation views remain as none of the photographers thought to bring along their cameras on the journey from Baroda to Bombay. ${ }^{2}$ Painters with a Camera has resultantly fallen out of the discourses of Indian artistic and photographic modernism. Available accounts of the exhibition confirm its objective to make an intervention in the museological and pedagogical standards of Indian institutions of display and education. ${ }^{3}$ Its participants appealed for the recognition of photography as an art practice at a time when the Lalit Kala Akademi (the National Academy of Arts) and the National Gallery of Modern Art, both centres of Indian modernism and its dissemination in the postcolonial period, had not yet begun to collect or display photography, still seemingly unconvinced by the machine-produced image and its artistic efficacy. ${ }^{4}$

The pamphlet's precarious placement in the present, only recently recovered and archived, speaks to the condition of a wider field of experimental photographic practices in India that have disappeared from circulation and knowledge. ${ }^{5}$ Simultaneously in Bombay, the Vision Exchange Workshop, or VIEW (I969-I972) became a space of fervent photographic and filmic production, such as Krishen Khanna's layered photographic series The Crows Around My Studio (c. 1975, figure 4) and Akbar Padamsee's intricate video works SYZYGY (I970) and the now-lost film Events in a Cloud Chamber (1969). Bhupendra Karia, a faculty member of the Graphics Department in Baroda from I964-66, set up VIEW's dark rooms while Nasreen Mohamedi, who would go on to join the Baroda faculty in the mid-I970s, was also at VIEW developing her starkly linear photographic practice (1967, figure 5). ${ }^{6}$ SNS Sastry, a director at the government-funded Films Division of India, similarly exhibited a tendency towards photographic montage in experimental films such as Yet In Him We Trust (I966, figure 6) 

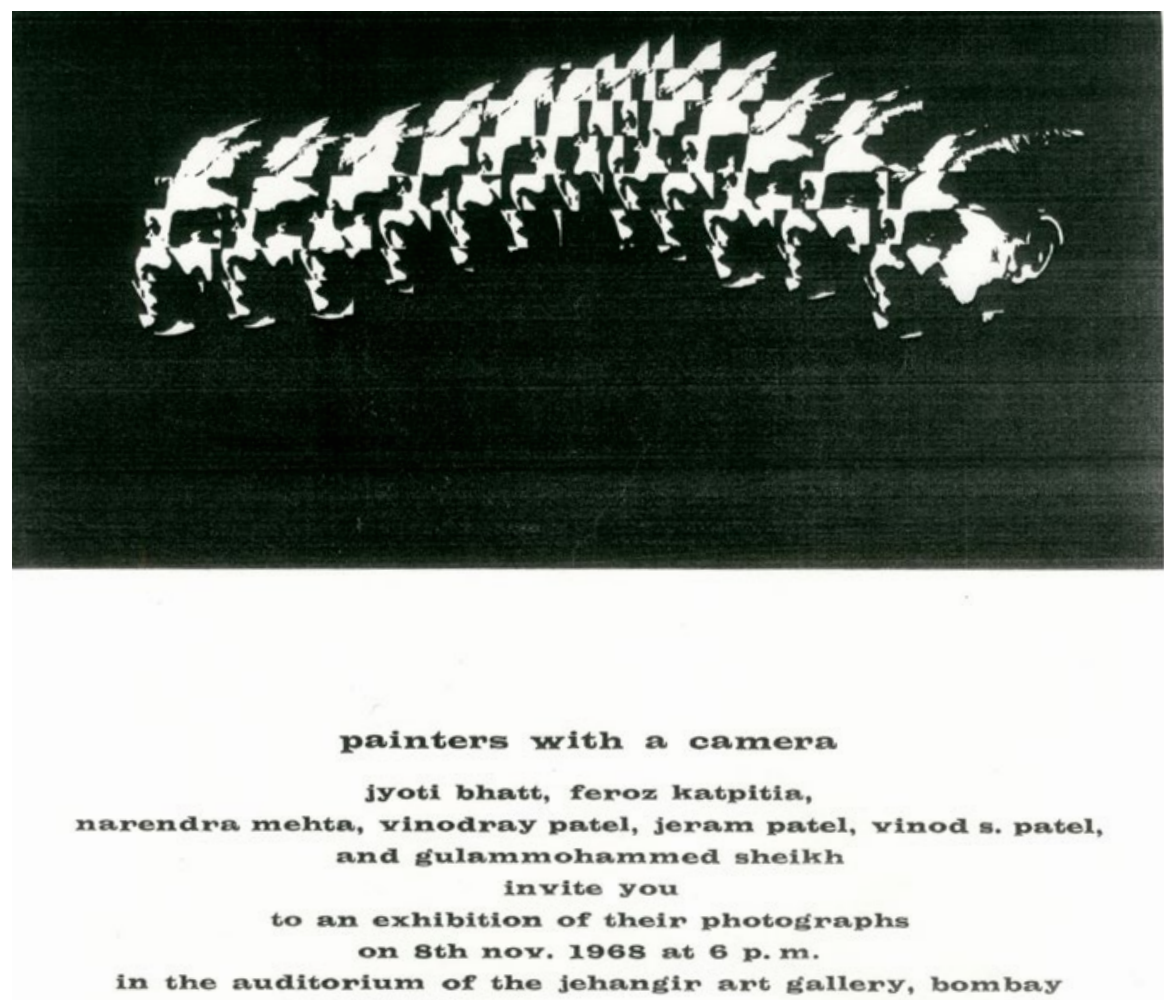

Figure 3 Invitation card for Painters with a Camera, I968. Jyoti Bhatt archive. Courtesy of Jyoti Bhatt and Asia Art Archive.

and Yes, It's On (1972). The abstracted, intentionally graphic turn taken by many of these artists, photographers and filmmakers in their work and their subsequent erasure has been attributed by Nancy Adajania to their status as 'no-context media', existing in the absence of a backdrop against which they could be 'named, identified, understood, and accepted' and of an identifiable prehistory that locates them. ${ }^{7}$ These practices ran roughly contemporary to the Baroda scene. A symbiotic relationship was sustained by the many interlocutors between the two, such as Karia and Mohamedi, as well as by the networks of exchange provided by artist-led journals, including Gulam Sheikh and Bhupen Khakhar's journal Vrishchik, which saw a number of contributors from Padamsee and Khanna. Although similar experimental endeavours based in Baroda have yet to be placed in this context, Painters 


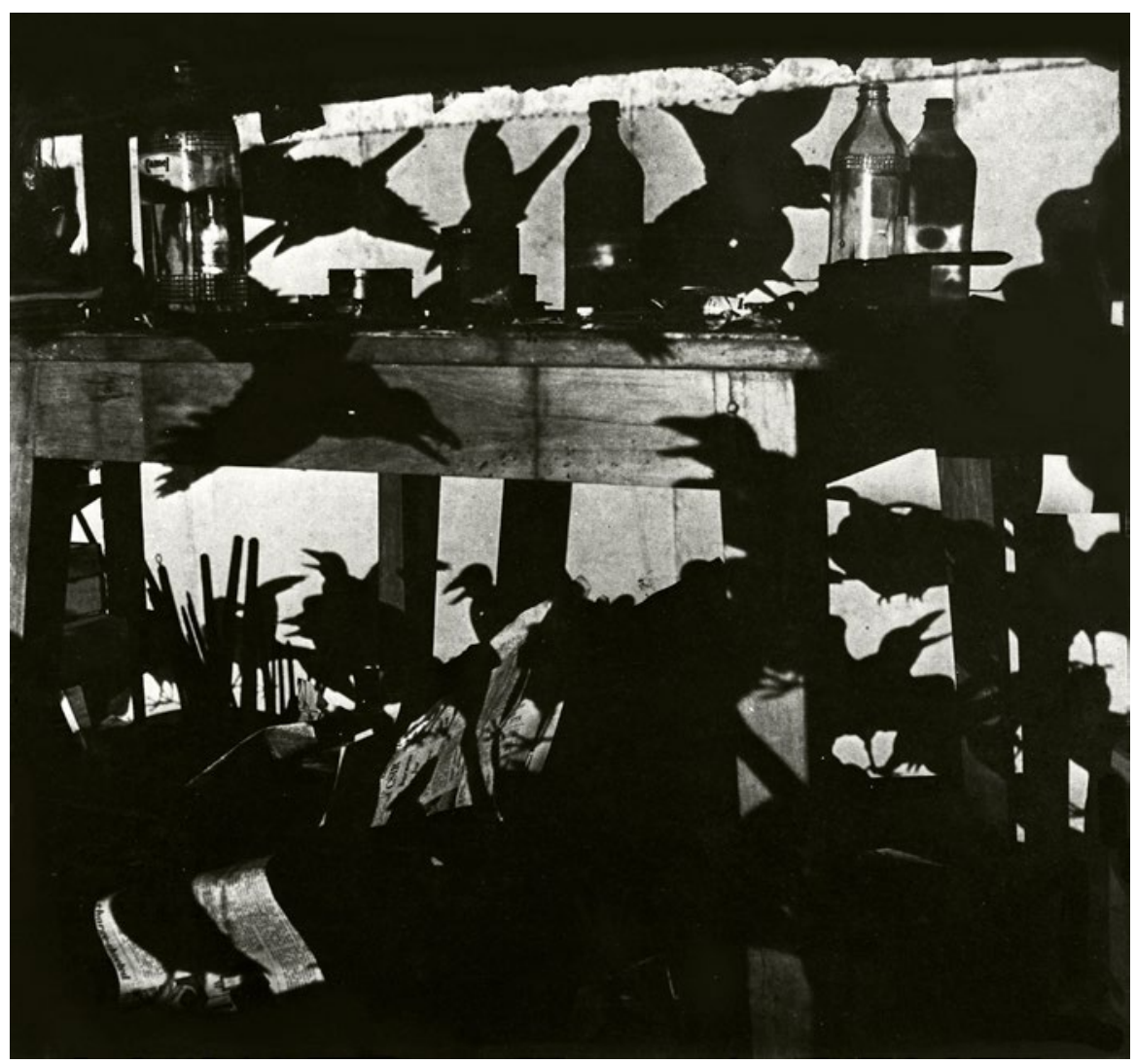

Figure 4 Krishen Khanna, The Crows Around my Studio, c. I975. Silver gelatin print. Courtesy of Karan Khanna.

With A Camera, which opened in Bombay, provides one such opportunity for reconciliation.

This paper will therefore address Painters with a Camera as a conduit into a broader study of Indian lens-based practices, their objectives and seeming disavowal of the aesthetics of postcolonial modernism. Noting a conscious turn on the Baroda artists' part to align themselves with Jehangir Art Gallery (by the I960s an established site for the display and generation of new notions of the artistic avant-garde) I will also inquire into the networks of vision and fragmentation that play out on the exhibition's title document. As I will argue, the photograph that came to be chosen as the exhibition's title image 


$$
\text { Painters With a Camera (i968/69) }
$$

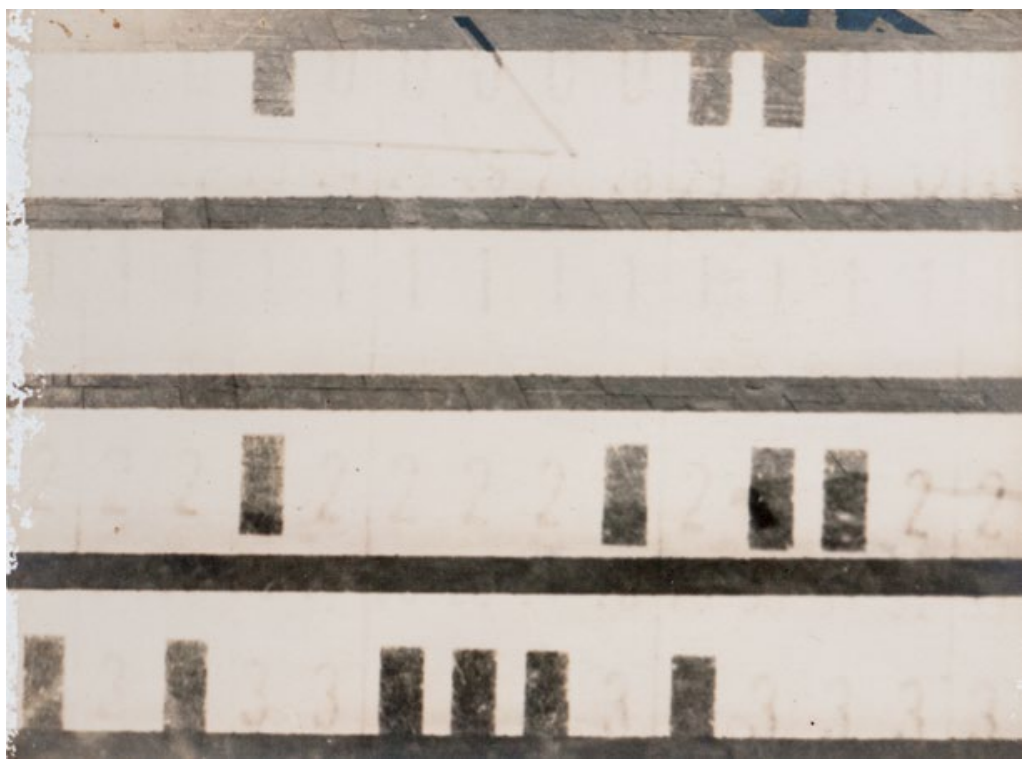

Figure 5 Nasreen Mohamedi, Untitled, I967. Silver gelatin print. Courtesy of Navjot and Sasha Altaf.

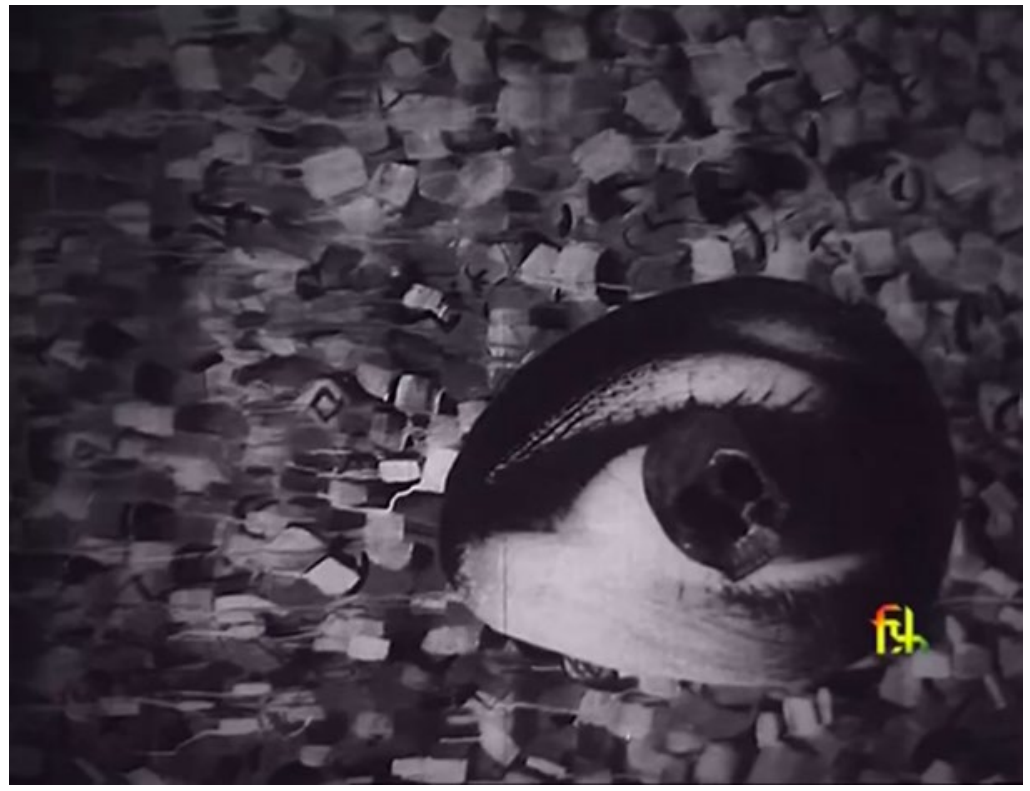

Figure 6 Still from Yet In Him We Trust, dir. SNS Sastry. Photo: author. 
opens up the ideological possibilities of photography with which the artists sought to align themselves. Drawing upon their varied engagements with Bauhaus photographer László Moholy-Nagy, I propose that the exhibitors mobilised techniques seeking to disrupt and rethink popular notions of the medium in modern India.

In an absence of visual records of the exhibition, its surviving participants have attempted to stitch together a description of what was on display. Jyoti Bhatt recalls that Jeram Patel and Gulammohammed Sheikh's photographs showed resemblances to the cinematic style of the French New Wave. The rest-Bhatt himself, Katpitia, Vinodray Patel, Vinod S Patel, and Mehtatransferred their negatives onto lith film ${ }^{8}$ and then enlarged them to create high contrast graphic prints, in broad sweeps of black and white. ${ }^{9}$ Bhatt included early versions of two photographs that were frequently revised over the subsequent years: Venice 1966 (c. I966-1969, figure 7) and Untitled ( $A$ Face) (c. I968-I969, figure 8), the latter created by merging a photograph of a peacock (printed as negative) into the outline of a face (printed as positive). Sheikh provides an account of the four images he displayed as part of the exhibition, including a horse grazing in his hometown Surendranagar and a portrait of the art historian Geeta Kapur, composed by montaging a negative and positive version of the same photograph. ${ }^{10}$

Vinodray Patel and VS Patel took on the task of designing the exhibition pamphlet, consisting of a title image, brief biographies of the artists, and a studio photograph of all seven. The artists' photograph was taken at a makeshift roadside studio in Baroda. An un-cropped outtake from Bhatt's personal archive (I968, figure 9) provides a broader look at the photographic scene, taken by an itinerant studio photographer: an elaborately-painted studio backdrop has been mounted over a doorway in the open street, its creases still visible despite the careful ropes and nails that attempt to stretch it into a realistic backdrop. In the final image, six of the photographers (sans Mehta) arrange themselves on and behind two flimsy metal chairs, where they pose with a collection of cameras, which Bhatt recalls borrowing from the studio's proprietor. The authorial photograph, and its carefully-considered juxtaposition with VS Patel's more playful, abstracted, composite image, operates as a visual foil, rendering the work of the painters with a camera distinct from that most commonly-encountered iteration of the camera in everyday Indian life. The exhibition pamphlet is thus a site of legible strategy 


$$
\text { Painters With a Camera (1968/69) }
$$

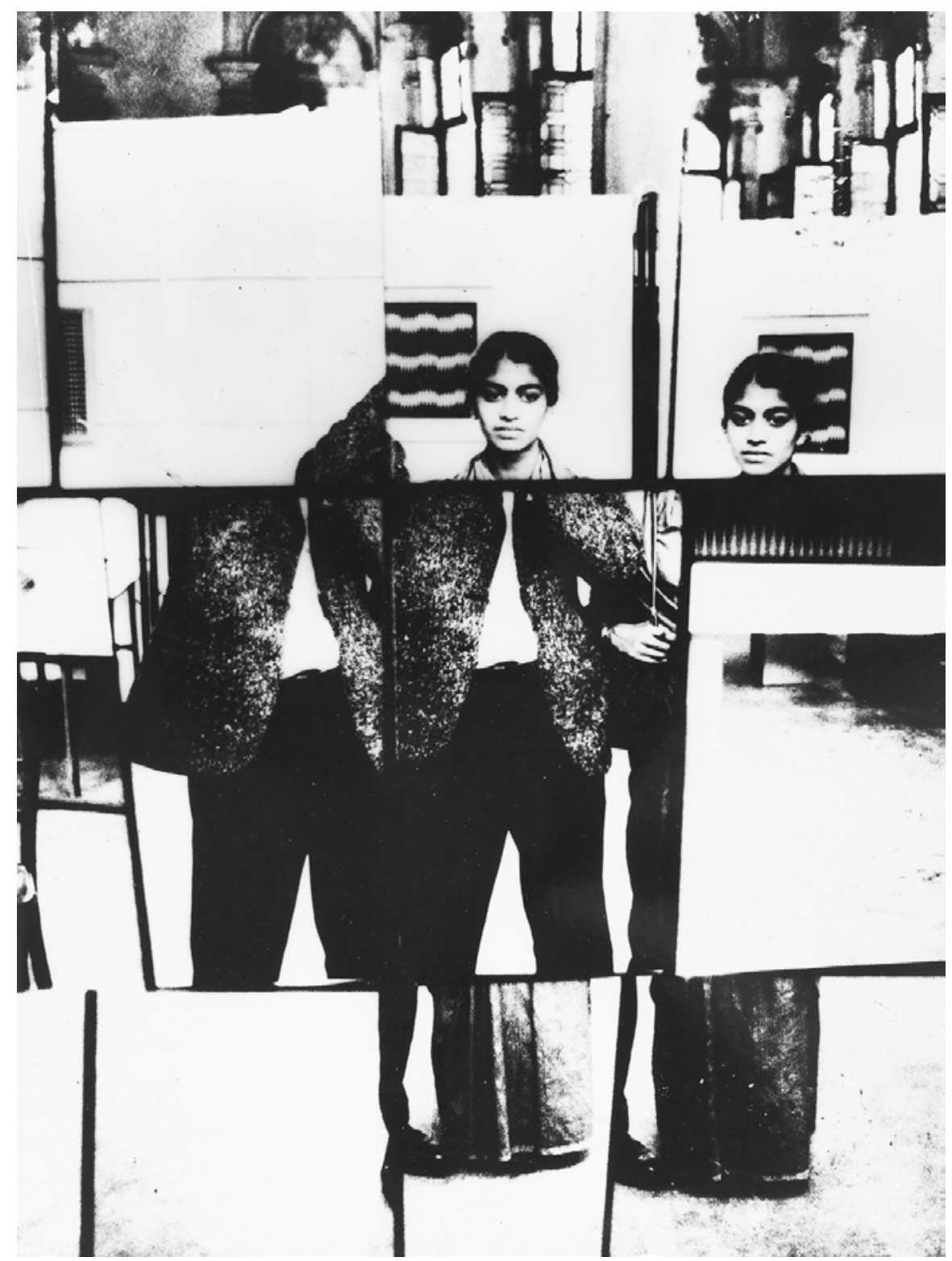

Figure 7 Jyoti Bhatt, Venice 1966, c. I966-I969. Silver gelatin print. Courtesy of the Museum of Art and Photography, Bangalore. 


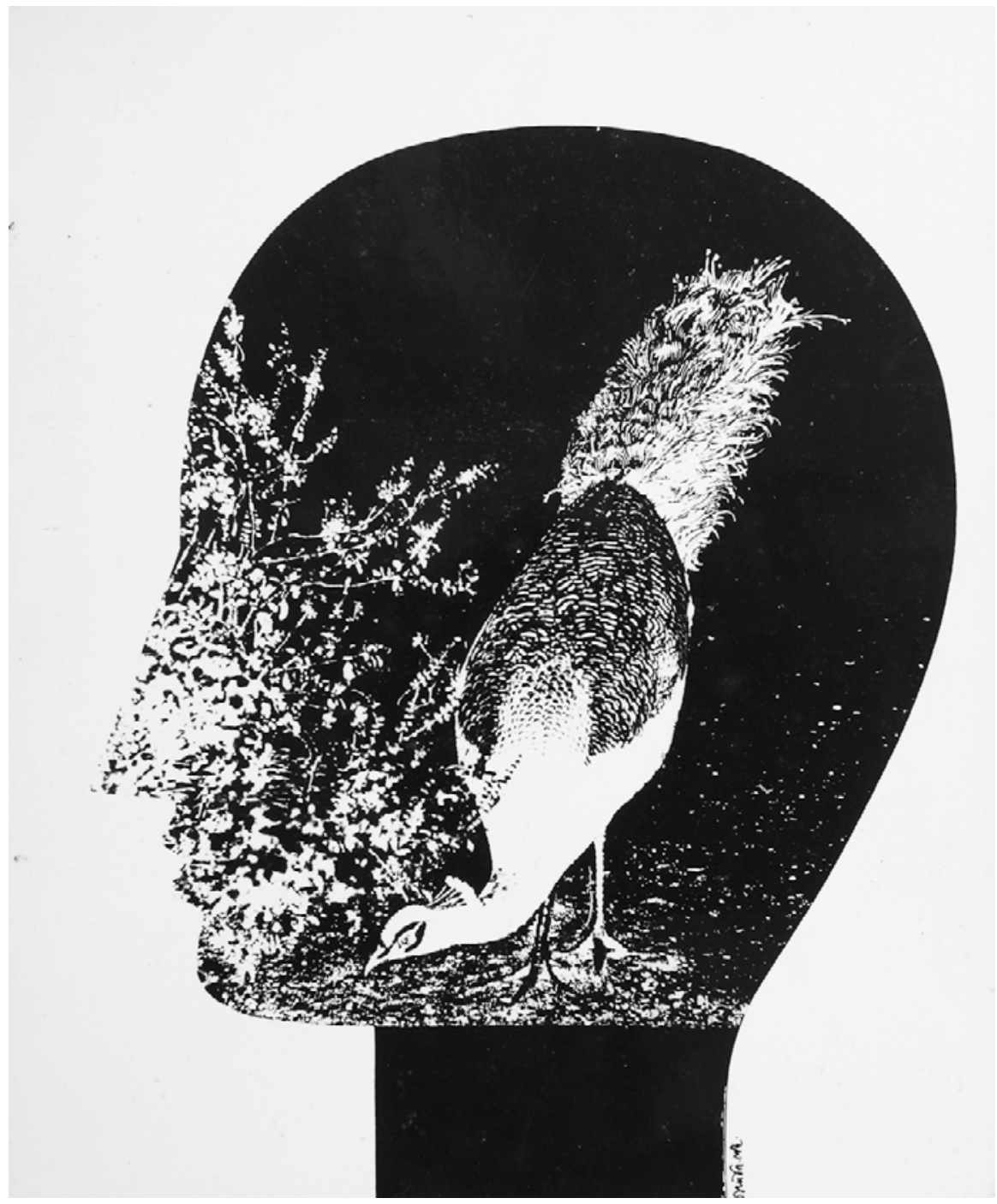

Figure 8 Jyoti Bhatt, Untitled ( $A$ Face), c. I968-I969. Silver gelatin print. Courtesy of the Museum of Art and Photography, Bangalore.

and also where the ontology of experimental photography is delineated or considered. It attempts to simultaneously render their photography distinct from the cultural uses and production of studio portraiture, as well as from the more artisanal practice of the painted studio backdrop. 


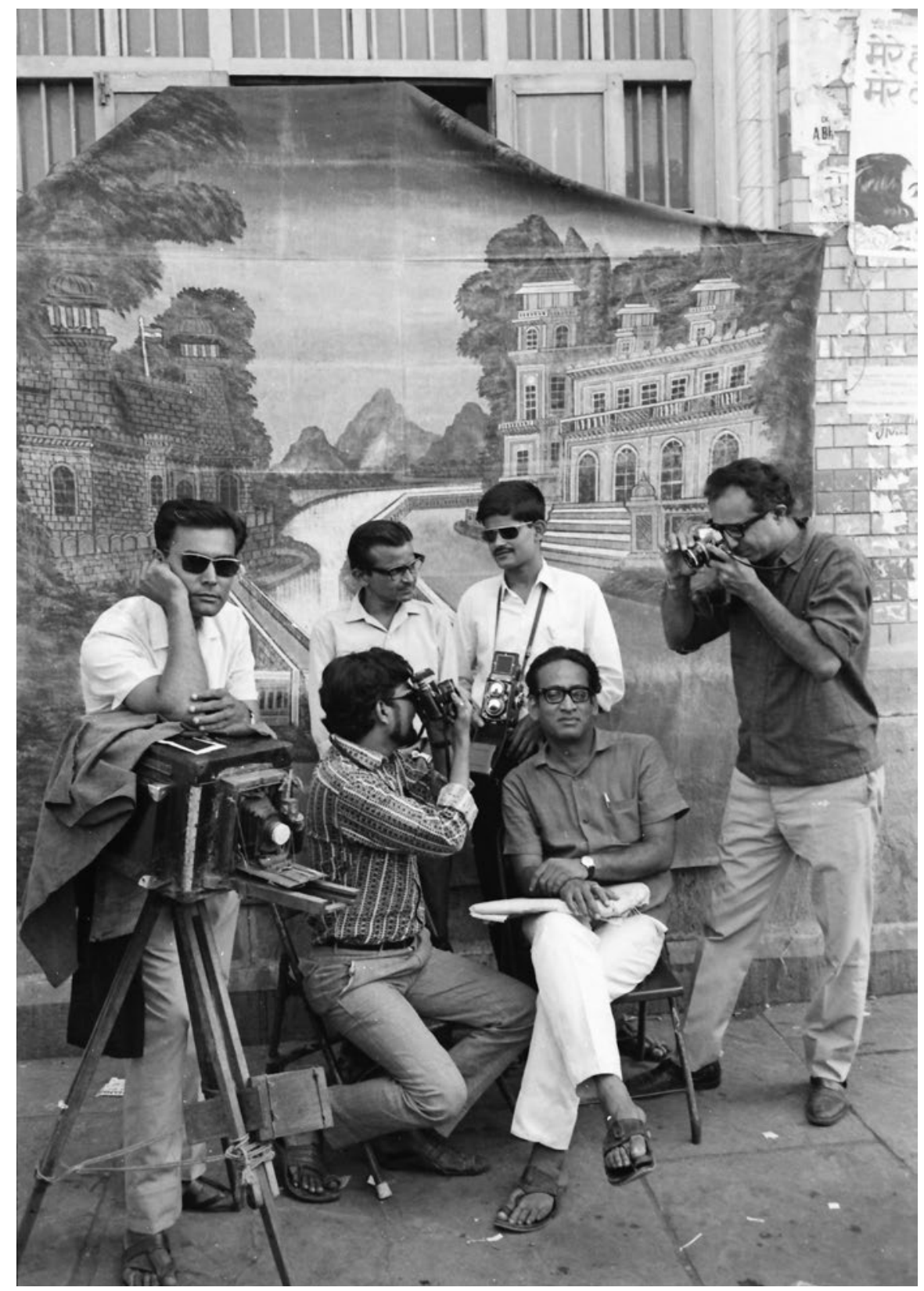

Figure 9 Photographer unknown, Painters as Photographers, I968. Dimensions unknown. Jyoti Bhatt archive. Courtesy of Jyoti Bhatt and Asia Art Archive. 


\section{O B J E C T}

The studio photograph displays the self-assured performances of homosocial camaraderie that are often at work in photographs from early days of Baroda's art school, when young men dominated the student rolls. The comical tone of the photograph, and its injection of the group's artistic practice into authorial portraiture, resembles photographic portraits of the Dadaists and suggests considered homage. While Bhatt leans low over a vintage view camera, Sheikh and Katpitia enact a sort of photographic duel, each turned away from the studio photographer to capture the other. VS Patel, whose Rolleiflex points outwards from the frame, seems to challenge the studio photographer. Narendra Mehta, then their professional superior, was not invited for the fun, and was only montaged into the image later on. Although the studio image hints at their own self-fashioning as photographers as they step into the medium of photography theatrically, their cameras akin to props, carefully-constructed photographs, such as the title image by Vinod $\mathrm{S}$ Patel, undermine the comic tone with their laboured repetition.

Although there is little formal resemblance between the two photographs in the exhibition pamphlet, they are conjoined in their shared engagement with the possibilities of vision and recognition. A rich ontological concern with vision in relation to the performance of modernity exists more broadly as a field of study in modern South Asia. ${ }^{11}$ In their theorisation of the symbiotic and discursive relationship of vision to public culture, Arjun Appadurai and Carol Breckenridge assessed Indian spectatorship in relation to an 'interocular field',

structured so that each site or setting for the socializing and regulating of the public gaze is to some degree affected by the experiences of the other sites. The interweaving of ocular experiences, which also subsumes the substantive transfer of $[\ldots]$ scripts and symbols from one site to another $[\ldots]$ is a critical feature of public culture in contemporary India. ${ }^{12}$

The notion of an embodied vision at the individual level, apropos Christopher Pinney, expands into a larger, loaded regime of vision in 'the vivid materiality of public visual culture'. ${ }^{13}$ Public culture here exists in the interstices between the domestic and national spheres, 'where different social groups [...] constitute their identities by their experiences of mass-mediated forms in relation to the practices of everyday life', ${ }^{14}$ developing beyond the 
confines of national culture, although not unmoved by changing politicocultural circumstances. The Baroda photographers' choice of Jehangir Art Gallery in Bombay as the venue for Painters with a Camera was, I argue, a purposeful act of public visual and temporal alignment with the gallery's own associations of modernity.

Designed by Durga Shankar Bajpai, Jehangir Art Gallery was among the first commercial, rentable, entirely extra-governmental art spaces, founded in I952 and became a democratic and dynamic space for the display of Indian art. ${ }^{15}$ It was established in the heart of colonial Bombay's colonial 'white' quarters, the Kala Ghoda area, flanked by the Bombay High Court, Bombay University, and the Prince of Wales Museum. The gallery's centrality to the city's art world was, in part, dependent both on its affordable hire charge and the stature of the artists who chose to exhibit there in its early years, including the members of the modernist Bombay Progressive Artists' Group. ${ }^{16}$ Print culture around the gallery offers much to the argument that Jehangir Art Gallery had, for the elite, urban echelons of public culture in Bombay, come to be considered as a theatre of an imagined and idealised modernism, both in its structure and location and in the visual culture that emerged around it. Atreyee Gupta notes a I953 advertisement in the magazine Art in Industry for the Associated Cement Companies Ltd. (henceforth ACC), featuring two montaged photographs of the gallery's interior and exterior, flanked by the following text:

For Art's Sake: India's most modern Art Gallery emphasizes the unique advantages of Reinforced Concrete for all types of construction. Beauty is wedded to strength in this modern structure which consists of Reinforced Concrete rigid frames spanning a spacious hall and projecting canopy at the entrance.

Through montage, the advertisement strategically creates an internally logical visual constellation that marries modern architecture and modern art on the foundations of modern building techniques (reinforced concrete). ${ }^{17}$ Tactically focusing on the interior of the gallery space, the advertisement reproduces a photograph of one of Jehangir's long, well-lit exhibition halls, unobstructed by pillars or supporting columns because of its concrete walls. What advertisements such as ACC's offer in addition to their products is, I 


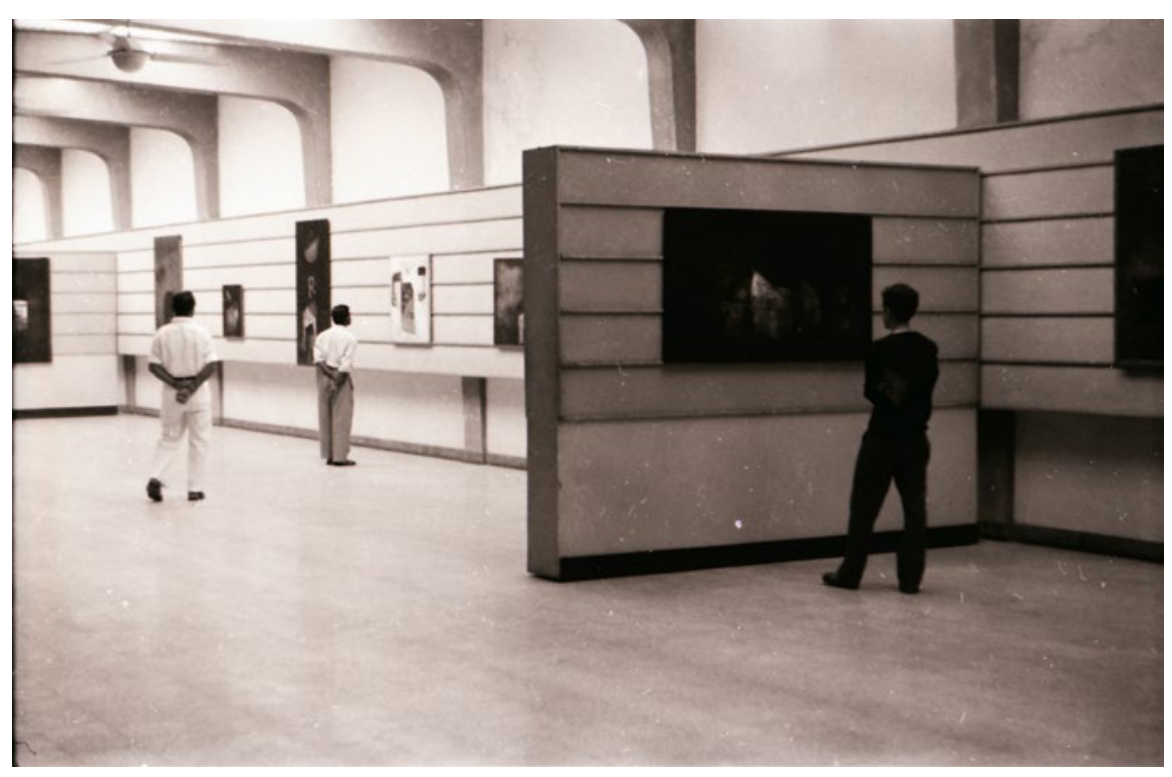

Figure Io Dashrath Patel, Untitled, c. I960-I965. Courtesy of Pinakin Patel.

suggest, the temptation of a Euro-American coeval modern within the gallery space, as the gallery consciously distanced itself from the surrounding Art Deco and Gothic revival buildings by staking a claim to the geographicallydiffuse vocabulary of the International Style. ${ }^{18}$

A similar scene unfolds in multimedia artist and designer Dashrath Patel's clandestine photograph taken in the same exhibition hall during his display of cubist collages (c. 1960-1965, figure I0). Here, the photograph proposes, viewers can partake in their own performance of cosmopolitanism, viewing, receiving and transacting with contemporary art. Each photographthe public and the private-intentionally and unintentionally depicts an assortment of viewers in both Indian and western dress as they peruse the paintings on display. The space of the modernist building becomes a site in which 'the face of modernity itself blasts us with its immemorial gaze'. ${ }^{19}$ Jehangir Art Gallery comes to signify a multi-layered, heterogeneous and ultimately performative site of intervisuality, where viewers consciously partake in a modern visual transaction. That the institution was invoked in print culture as a pinnacle of Bombay's arrival into the twentieth century, 
and was also received as such, suggests what was at stake in the Baroda photographers choosing to display their work there.

Moreover, the gallery was no stranger to the display of photography: it was at Jehangir that the Indian iteration of Edward Steichen's monumental exhibition The Family of Man was put on display from I 8 June to I 5 July 1956. This would be the only Indian art gallery where the exhibition was displayed; it was housed at an industrial fair ground in Delhi during a UNESCO Conference in November 1956, at universities in Agra and Madras, and at Ranji cricket stadium in Calcutta. It was also here that the Bombay Photography Association put up Images of India, a regionally-specific response to the Family of Man, in 1960. ${ }^{20}$ To display at Jehangir offered purposeful alignment with its brand of syncretic modernity, as well as a means of elevating the status of the composite photograph. In the case of Painters with a Camera, the exhibition's disappearance from a broader history of Indian modernism makes it difficult to ascertain the success of this endeavor, and to know more about the reception of the exhibition.

The photograph that was finally put into the pamphlet for Painters With a Camera equally suggests an intentional parody of the possibilities of photography and the fragmentation of ocular vision by the profusion of the camera. The authorial image with which it is paired equally creates an elaborate network of performed photographic encounters that illustrate the intervisual through the implications of multiple simultaneous authorship and viewership. The profusion of lenses in the frame is of interest; ranging from the dark or tinted glasses worn by Jyoti Bhatt, Vinod S. Patel, Vinodray Patel, and Narendra Mehta, while Gulam Sheikh and Feroz Katpitia are each preoccupied by their camera viewfinders. This excess of cameras and ocular equipment is occasionally confronted in the image by the impermissible dark glasses of the photographers and the closed lens on Bhatt's camera. In this tension between the lens as all-seeing and all-recording, with an authorial photograph that is rich with ocular potential, the photograph points both to the fragmentation and multiplication of vision and its outright denial of compositional wholeness. The image seems to stand in for the photograph's simultaneous multiplicity and fragmentation. This speaks not simply to the photographic practice of the Baroda practitioners but also to their Bombay counterparts, whose experimental explorations of composite photograph were 'either ignored or grudgingly accepted as career aberrations'. ${ }^{21}$ Here the 
multiplicity of machinic modes of visions among the photographers in the Painters with a Camera publication seems to speak to and resist the dominant institutional blindness towards photography at the time.

As teachers at the Faculty of Fine Arts at the Maharaja Sayajirao University of Baroda, it appears that the seven mostly engaged with photography extraneously due to the lack of official encouragement of the medium. The Faculty was established in I950 as the newest department within the MS University, formed a year previously at the behest of the Maharaja Pratapsingh Gaekwad who was acting upon the kingdom's long nationalist movement towards autonomy in university pedagogy. ${ }^{22}$ Documents from the Report from the Baroda University Committee of 1948 reveal how in their frequent negative invocations of the University of Bombay and its colonial baggage, its founders 'refashioned [the university] as a non-colonial, or rather "decolonial" weapon' in their desire to produce a specifically Indian iteration of pedagogy at Baroda. ${ }^{23}$ It was with similar sentiment that the Faculty of Fine Arts was founded a year later, intending to set the pace and terms for postcolonial Indian art practice. Previously existent art schools in erstwhile British India had been intended '.. to supply skilled draftsmen, designers, engravers, to meet increasing demand' in the imperial economy. ${ }^{24}$ The art schools of Madras and Lahore, prominent in twentieth-century colonial India, were central to the mechanisation of artisanal practices in their emphasis on restoring the artisan to pre-industrial excellence via industrial workshop pedagogy. ${ }^{25}$ By contrast, the founders of the Faculty of Fine Arts sought dramatic rupture from colonial traditions, focusing on individual selfexpression in a new liberal artistic climate. ${ }^{26}$ Karin Zitzewitz notes that the Faculty was established with two models in mind: the 'post-Bauhaus American art schools' and Baroda's own Kala Bhavan, an artistic and technical institute also established by Maharaja Sayajirao in I 89I, where the vernacular Gujarati was the mode of instruction. ${ }^{27}$ The formation of the Faculty of Fine Arts gained both from the successes and personnel of its predecessor. Furthermore, that the art school was established in a former princely state in Gujarat, far removed from the colonial cities of Bombay, Madras, and Calcutta, created new lofty pedagogic preoccupations for the institution to perform 'as part of the fervour and promise of a new and independent India'. ${ }^{28}$

The first prospectus for the art school begins with a brief essay by Hansa Mehta, the vice-chancellor of the University of Baroda, and former 
diplomat and associate of Jawaharlal Nehru. Mehta writes: 'the product of this education may not become a great artist, but he certainly would acquire an intellectual understanding of art'. ${ }^{29}$ Speaking of a thematic and formal vacuum in postcolonial India, she noted that 'we have lost our originality and either copy the western forms of art or the ancient Indian forms' - her writing imbued with a sense of loss of the 'authentic' that the Baroda Faculty sought to fill. ${ }^{30}$ In this context many artists, such as Sankho Chaudhri, Ramkinker Baij, and KG Subramanyan, came from the Kala Bhavan at Shantiniketan in Bengal, established in I9I9 as an early site of trans-Asian modernism and anticolonial protest, as well as from the new politically-charged artistic climate of Bombay, including NS Bendre, a member of the Bombay Progressive Artists' Group. Markand Bhatt, who had recently returned from the Barnes Foundation in the United States, was asked to found the Faculty in I 949 and create the structure of its educational programme, where he remained until I959.

Although early students (including most of the 'painters with a camera') were encouraged to engage with 'Oriental and Western traditional paintings', to 'study from life, mural decoration, elements of portraiture [... and were recommended the] study of modern art and the comprehensive study of Indian and Western arts' ${ }^{\prime 3}$, photography was to be taught under the Applied Arts department and as a two-year certificate course. It was later reduced to a subsidiary subject in the Applied Arts department - students of the Department of Painting, such as Bhatt and Katpitia were never taught photography formally, and thus depended on the benevolence of Narendra Mehta, and his assistant, Ramachandra Kadam, for use of the dark rooms.

The exact interest or manifestation of the Bauhaus in Baroda is debated. That Markand Bhatt was a proponent of Bauhaus pedagogy in India, although undeniable, is yet to be more specifically established with reference to the Baroda Faculty's curriculum. It is, however, made manifest in the Faculty's emphasis on the exploration of 'individuated, intuitive energies', and on materiality. ${ }^{32}$ Moreover, the inclusion of the work of Moholy-Nagy in the Faculty syllabi would not necessarily have spelled any explicit rupture from the Bengal school - in fact, the interest in the Bauhaus at Baroda could have been informed by an earlier legacy of the German school's allegiance with their Bengali counterparts. This was a network of friendships and solidarity with an anti-colonial cause that culminated in the Bauhaus exhibition organised 
by the Indian Society of Oriental Art in Calcutta, I922, where the works of Santiniketan practitioners Rabindranath and Gaganendranath Tagore were shown alongside that of painters Johannes Itten and Georg Muche. ${ }^{33}$ The Bauhaus itself, in sites such as Calcutta and Baroda, had come to connote extra-colonial modernism, a source of industrial critique and aesthetic inquiry into modernity beyond the reach of British colonial authority. Unpublished essays by Jyoti Bhatt that make reference to Moholy-Nagy's writing on photographic literacy suggest that he encountered the latter's writing in all likelihood around the Faculty of Fine Arts. Bhatt's essays and his engagement with the Bauhaus further raise the possibility that Painters With a Camera itself displayed a techno-optimistic interest in the camera 'as cure', producing a new system of optics - not simply a means of reproduction but also 'a way to bringing (optically) something entirely new into the world'. ${ }^{34}$

The Faculty of Fine Arts' pedagogical hesitation to include the study of photography in many ways mirrors the Bauhaus's late adoption of the camera, although many decades later. It is possible that many of the founders of Baroda, who came from Santiniketan, inherited their disdain for photography from their own teachers. Nandalal Bose, the longstanding principal of Santiniketan's art school and an established anti-colonial painter from the Bengal School, wrote:

In a photograph one can exactly reproduce the details of a natural object. But however good a photograph is, it is not a painting ... the camera is a mere tool. Since it has no heart or intellect it merely catches the exact details of whatever is in nature. While painting a scene or an object, an artist selects as much as is needed from natural objects ... not copying, but making a selection. ${ }^{35}$

Bose's suspicion of the camera may well have come from his teacher Abanindranath Tagore, who wrote that the photograph is capable of 'veracity but not variety'. ${ }^{36}$ The assumption of photography's irredeemable foreignness (uncontested even by the proponents of the medium) was an added source of anxiety for de-colonial art pedagogues. An article on the history of Indian photography in the Bombay-based cultural quarterly magazine $M A R G$ (I960) works within this rubric of photography-as-foreign, admitting that 'photography is not part of the traditional Indian cultural heritage' before proceeding to make a case for the medium as an opportunity to 'breath[e] 


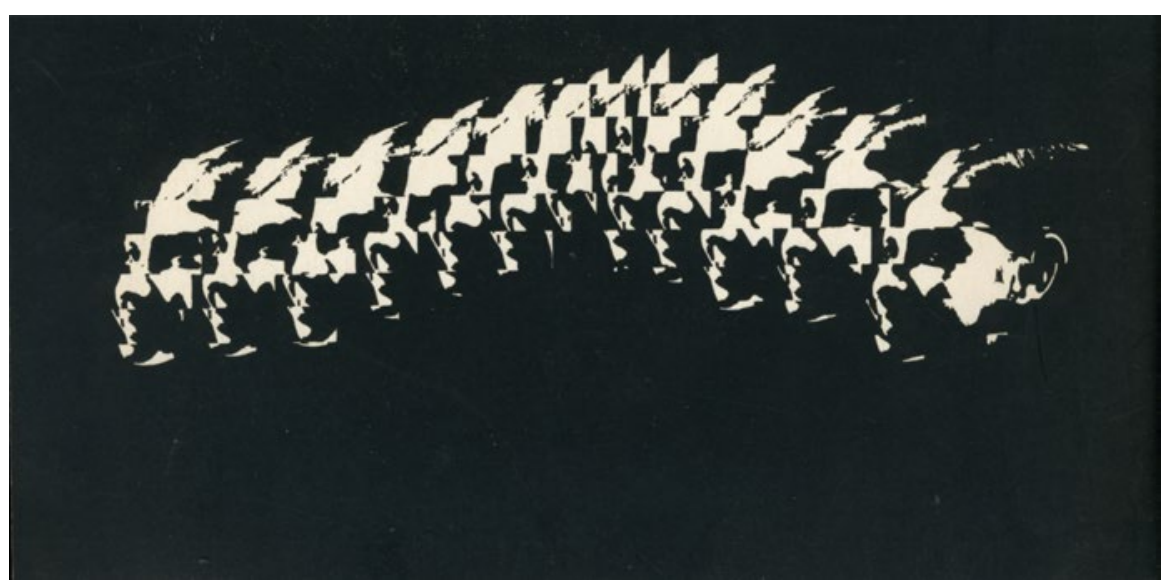

Figure II VS Patel, Untitled (portrait of Vinodray Patel), c. I968. Jyoti Bhatt archive. Courtesy of Jyoti Bhatt and Asia Art Archive.

in other traditions' ${ }^{37}$ Aside from the conviction in the camera's irrevocably colonial status, most criticisms of photography within Indian art pedagogy are unsurprisingly reminiscent of earlier anxieties about the camera in Europe and the United States. Early criticisms of photography within art practice frequently deployed disembodiment as a metaphor for incompletion; the photograph was said to entail an inherent lack, a removal from human intactness for its introduction of a mechanical eye. ${ }^{38}$ In this iteration of modernism in a former colony, then, photography was largely unwelcome. In contrast, the Baroda-based participants of Painters With A Camera were interested in the camera's ability to 'bring about aspects of the original that can be accessed only by the lens [...] and not by the human eye [... Capturing] images that are quite simply beyond natural optics'. ${ }^{39}$ Turning the status of the camera as a 'mere tool' on its head, the photographers celebrate the photographic plane as a site of physical and imaginative labour, disrupting the mechanical expectations of camera apparatus through manual intervention. ${ }^{40}$

[fig. I I] It is tempting to suggest that the seven photographers in Painters with a Camera were not only protesting the narrowness of the curriculum in their native Baroda, but also making a case for the camera itself as being able to produce its own specific responses to modernism through the machine. It was perhaps for its presentation of the many ontological possibilities of the photograph in relation to time and trace that VS Patel's photograph 
of Vinodray was chosen to represent the exhibition as its title image (c. I968, figure II). In Patel's photograph, the repetitions of the face and its abstraction into motif creates a chain of motion against an unvarying black background. He likely began by creating a high contrast print of Vinodray's face on fine photographic paper. Multiple renderings of the face were printed repeatedly and then laboriously arranged from left to right to create the effect of a chain, before transferring the now-composite print onto lith negative film in order to render it against a deep black background. Although Patel's prints of the face begin uniformly, reproducing the same portion of the face at regular intervals, the centre of the frame features an aberration - a systemic kink - that creates a cluster of dense, merged-together contortions of the silhouette. Here Vinodray Patel's likeness is obscured by the intensity and number of its own reproductions and the imperfections of manual repetition, dispersed into fragments of multiple viewpoints that overwhelm and evade simple recognition. The central aberration lends the photograph a dizzying quality as it alters the presumed relationship among the facial fragments: are they mutations in a series of infinite reproductions, or staggered manifestations of a face as it briefly turns away from the camera? In its gradual unfolding across the space of the composition, the image brings to mind Moholy-Nagy's mobilisation of repetition as a 'space-time organisational motif, which [...] could be achieved only by means of the technical, industrialized system of reproduction characteristic of our time', ${ }^{41}$ In a later linocut published on the cover of Sheikh and Bhupen Khakhar's monthly magazine Vrishchik in November I97I (c. I97I, figure I2), Patel's linocut adaptation of a photograph of Jorge Luis Borges is similarly abstracted by repetition. Although the imperfect reproductions of the linocuts and their spatial arrangement may allude to Borges's elaboration upon simultaneous temporalities in his fiction, the work tests the limits of seriality, reproduction and medium-specificity. ${ }^{42}$ The precise purpose of Patel's camera in his composite photograph of Vinodray is to create tension between appearance and disappearance, blurred and repeated into an assembly-line motif that reconciles mechanical movement and the jilted motions of the hand. Reminiscent of Moholy-Nagy's composite photograph The Law of Series, the dissolution of the individual face in favour of dispersion and repetition tilts the exploration of the camera's distinct potentialities precisely away from its machinery. 


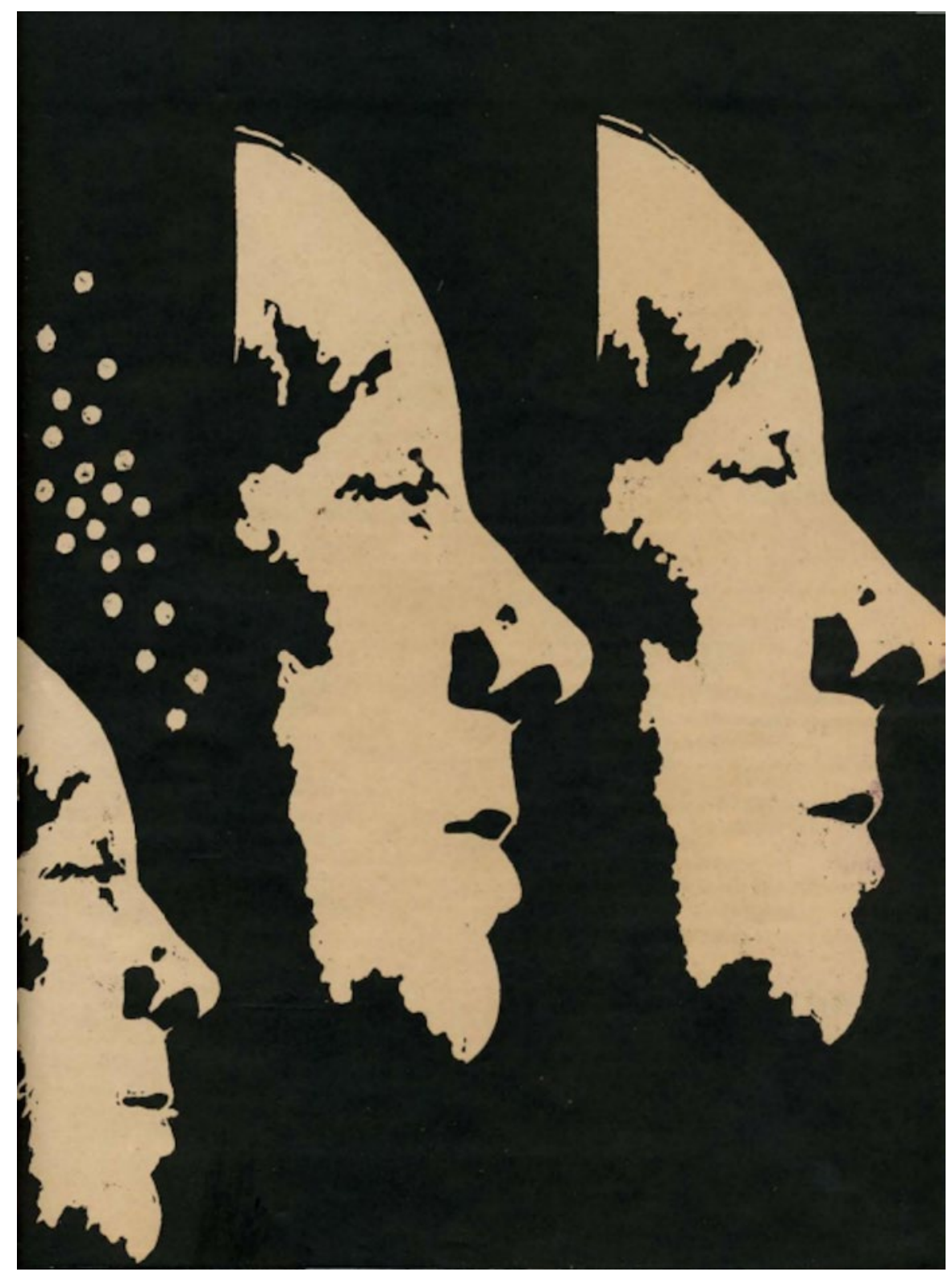

Figure I2 VS Patel, Jorge Luis Borges, c. I97I. Linocut on letterpress. Gulamohammed Sheikh archive. Courtesy of Gulamohammed Sheikh and Asia Art Archive. 
This was a promise of photography that had come to be recognised in the Baroda artists' own generation. Closer to home, the Indian art critic and photographer Richard Bartholomew, roughly contemporary to the artists and a proponent of their artistic practices, had extolled a similar purpose for the photographic medium in a I960 article, writing: 'what photography has to fight against is the commonplace, the mundane, the workaday, the rejected, spent images which the eye [...] cannot ignore'. ${ }^{43}$ In its panoramic suggestion of motion, Patel taps into a broader history of photography, wherein the image registers the motion and duration of which it is forged. In the case of Patel's photograph, however, this motion appears not before the lens but behind it; the photograph is a register of the photographer's own repeated manual labour over the central motif as it oscillates repeatedly between positive and negative space, echoing the composite nature of Bhatt's Untitled ( $A$ Face). The rehabilitation of the machinic image through manual collaging has specific temporal connotations for the image: time in the photograph is connoted as a stutter, unfolding severally and simultaneously across the frame. Whereas the unseen lines that divide the face into alternating components of negative and positive space seem to suggest the multiple states in which the image is impressed upon the photographic plate, the repeated prints suggest the photograph's own infinite reproducibility. The placement of Patel's photograph at Jehangir Art Gallery indicates both the group's intentional alignment with machinic images for their ability to produce fracturing and displacement, and the simultaneous appropriation of those machinic images to manual ends. Here painstakingly rendered distinct both from vernacular studio-based practices and from the mechanical expectations of photographic modernism, the composite photograph is achieved and articulated as a site of multiple disorderings, expanding the scope for photographic vision in Indian artistic practice.

\section{Notes}

I Made accessible by Asia Art Archive, a Hong Kong-based organisation that creates digital archives of artists' personal collections, photographs, and essays, and correspondence.

2 This paper uses the cities' former names, Bombay and Baroda, rather than Mumbai and Vadodara (changed in I995 and I974 respectively).

3 Fleeting references are made to this presumed ban: JN Unwalla, in the article 'Indian Photography -50 Years', writes: 'In India the story of Photography ... is not very 


\section{Painters With a Camera (I968/69)}

heartening. The Government has yet to give it official recognition as an expressive art form ... the next few years will undoubtedly be for this search for recognition and unity ...' Unwalla, JN. 'Indian Photography - 50 Years' in MARG, vol. I4, no. I, I960, pp. 5-IO. In I97 I Jyoti Bhatt flouted the Lalit Kala's prohibition of photography in their annual exhibition by submitting $A$ Face with the medium description 'silver gelatin print' (rather than 'photograph'), because of which it went undiscovered and was selected for display by the jury. Interview with Jyoti Bhatt, 24 January 2017.

4 This of course has parallels in interventions made in the United States and England in the late nineteenth and early twentieth centuries, when groups such as the Linked Ring and Alfred Stieglitz's Photo-Secession campaigned for the camera's status as art by staging regular photography exhibitions.

5 Simultaneous iterations of photographic modernism in other non-European nations are addressed in Esther Gabara, Errant Modernism: The Ethos of Photography in Mexico and Brazil, Durham NC, 2008; Judith Keller and Amanda Maddox (eds.) Japan's Modern Divide: The Photographs of Hiroshi Hamaya and Kansuke Yamamoto, Los Angeles, 2013; William Schaefer, Shadow Modernism: Photography, Writing, and Space in Shanghai, 19251937, Durham NC, 20I7. In the study of Indian photography, there continues to be a prominent imbalance towards the study of nineteenth and early twentieth-century photography with a number of prolific engagements with colonial photographic culture and early Indian practitioners in texts such as Christopher Pinney, Camera Indica: The Social Life of Indian Photographs, London, I997; Zahid R. Chaudhary, Afterimage of Empire: Photography in Nineteenth-century India, Minneapolis MN, 20I2. More recent literature has paid close attention to photography and memory, such as in Postdate: Photography and Inherited History in India, exh. cat., San Jose CA, 2015.

In the specific context of mid-twentieth century India, monographs on photography have pertained primarily to photojournalists such as Homai Vyarawalla and Sunil Janah in Sabeena Gadihoke, Camera Chronicles of Homai Vyarawalla, Ahmedabad, 2006; Ram Rahman, Sunil Janah: Photographs 1940-1960: Vintage Prints from the Swaraj Art Archive, Noida, 20I4. Studies of artists' excursions into photography are largely restricted to exhibition catalogues such as Nasreen Mohamedi: Waiting is a part of Intense Living, exh. cat., Madrid, 20 I5; Jyoti Bhatt: Parallels that Meet, exh. cat. New Delhi, 2008; and more recent engagements with artistic practice including Rebecca Brown, Art for a Modern India, 1947-1980, Durham NC, 2009; Emilia Terracciano, Art and Emergency: Modernism in Twentieth-Century India, London, 20 I 7; however a comprehensive, interconnected account of these photographic practices has yet to be written.

6 See Murtaza Vali, Ashim Ahluwalia: Events in a Cloud Chamber, exh. doc., Mumbai, 20I6; Shanay Jhaveri and Nalini Malini ,'Building on a Prehistory: Artists' Film and New Media in India, Part 3', LUX, 24 June 20I4: https://lux.org.uk/writing/buildingprehistory-artists-film-new-media-india-part-3 (date accessed: 24 July 20I 8 ).

7 Nancy Adajania, 'New Media Overtures Before New Media Practice in India' in Gayatri Sinha (ed.) Art and Visual Culture in India, 1857-2007, Mumbai, 2009, pp. 26628I.

8 A form of camera film that was known to produce particularly high contrast images; photographs in the positive could be contact printed onto lith film in order to yield a larger, high contrast negative. 
9 Jyoti Bhatt, Baroda, personal communication, 25 September 2017.

IO Ibid.

I I The notion of loaded, potent acts of sight and seeing (using such terms as 'nazar', 'darshan', and 'corpothetics' recurs in methodologies that unpack the specificity of visual transactions in the Indian subcontinent and their manifestations in public culture. See Carol Breckenridge (ed.) Consuming Modernity: Public Culture in a South Asian World, Minneapolis MN, I995; Shaila Bhatti, Translating Museums: A Counterhistory of South Asian Museology, Abingdon, $20 \mathrm{I} 2$.

I2 Carol Breckenridge, Arjun Appadurai, 'Public Modernity in India', in Carol Breckenridge (ed.) Consuming Modernity: Public Culture in a South Asian World, Minneapolis, I995, pp. I-20, p. I2.

I 3 Christopher Pinney, 'Introduction' in Rachel Dwyer and Christopher Pinney (eds.) Pleasure and the Nation: The History, Politics and Consumption of Public Culture in India, New Delhi, 200I, pp. I-34, p. I.

I4 Breckenridge, pp. 4-5. The historiographies of public culture and viewing are closely intertwined in the study of twentieth-century India, and have been mobilised variously in studies of local film, cricket, and urban restaurant culture, and strangely have yet to make their way into to the study of 'secular' artistic viewing. See Breckenridge, Consuming Modernity, I995; Dwyer and Pinney, op. cit.; Martin Jay and Sumathi Ramaswamy (eds.) Empires of Vision: A Reader, Durham NC, 2014.

I5 See Rahul Mehrotra and Sharada Dwivedi, The Jehangir Art Gallery: estd. 21 January, 1952. Mumbai, 2002; Karin Zitzewitz, The Art of Secularism: the cultural politics of modernist art in contemporary India, London, $20 \mathrm{I} 4$.

I6 See Karin Zitzewitz's detailed interviews with Kekoo Gandhy, whose framing business (the Chemical Moulding Manufacturing Company) and subsequent art gallery (Gallery Chemould) were physically located inside of the Jehangir Art Gallery until 2007 (pp. 87-88).

I7 Atreyee Gupta, The Promise of the Modern: State, Culture, and Avant-gardism in India (ca. 1930-1960), unpublished doctoral thesis, University of Minnesota, 20 I I, pp. I06-I09.

I 8 For a discussion of co-evalness and co-temporality, see Johannes Fabian, Time and the Other: How Anthropology Makes its Object, New York, I983.

I9 Walter Benjamin, The Arcades Project, (trans.) Howard Eiland and Kevin McLaughlin, I982, repr. Cambridge MA, 2002, pp. 22-23.

20 See MARG, vol. I4, no. I, titled Photography: Images of India, in which details of the exhibition and its constituent works were reproduced. The relationship of The Family of Man and Images of India is briefly addressed in Atreyee Gupta. 'Belatedness and Simultaneity: A Short History of Photography from India' in Postdate: Photography and Inherited History in India, exh. cat., San Jose, CA, pp. 24-35.

2 I Adajania, p. 270.

22 Manu Bhagavan presents a cogent account of Maharaja Pratapsingh's grandfather Maharaja Sayajirao Gaekwad III's extended struggle to establish the University of Baroda, eventually allowing the movement to lapse in I930, in large part because of the Maharaja's fear of dethronement at the hands of the displeased imperial government. See Manu Bhagavan, 'The Rebel Academy: Modernity and the Movement for a 


\section{Painters With a Camera (I968/69)}

University in Princely Baroda, I908-49', in The Journal of Asian Studies, vol. 6I, no. 3, 2002, pp. 919-947.

23 Ibid., p. 944.

24 Author Unknown, Rules of the Society for the Promotion of Industrial Art (Calcutta I 856) quoted in Gupta, p. 29.

25 For a detailed account of the curricula of colonial art schools, see Arindam Dutta, The Bureaucracy of Beauty: Design in the Age of its Global Reproducibility, New York, 2007, pp. 32-33.

26 See Gulammohammed Sheikh (ed.) Contemporary Art in Baroda, New Delhi, I997.

27 Zitzewitz, p. 44.

28 Amrita Gupta Singh, "Tradition and Innovation: The Past as Resource" in Jyoti Bhatt: Parallels that Meet, exh. cat., New Delhi, 2007, pp. 24-49, p. 29. See also Rebecca Brown, Art for a Modern India, 1947-80, Durham, NC, 2009.

29 Hansa Mehta, 'Foreword' in Faculty of Fine Arts: The Maharaja Sayajirao University of Baroda, university prospectus, I953, n.p.

30 Ibid.

3 I Author Unknown, 'Outline of Courses' in Faculty of Fine Arts: The Maharaja Sayajirao University of Baroda, university prospectus, I953, n.p.

32 Sheikh, p. 267 (footnote 6).

33 Regina Bittner and Kathrin Rhomberg (eds.), The Bauhaus in Calcutta: An Encounter of Cosmopolitan Avant-Gardes, exh. cat., New York, 2013.

34 See Pinney's consideration of Indian photography as poison and as cure. In his text The Coming of Photography in India (2008), Pinney invoked a dichotomous distinction in camera practices of the late nineteenth century: where cure denotes the jubilant adoption of the camera in various bureaucratic capacities as a means of solving "existing representational problems' in the imaging of India, the camera turns poisonous when the images it generates begin to favour the cause of the colonized. For the formerly colonised, I would argue, the stages of cure and poison are reversed. Laszlo MoholyNagy, 'From Pigment to Light', in Vicki Goldberg (ed.) Photography in Print: Writings from 1816 to the Present, Albequerque NM, I98 I, pp. 339-348, p. 344.

35 Nandalal Bose, Vision and Creation, Santiniketan, I999, p. 247.

36 Tagore quoted in Natasha Eaton, Colour, Art, and Empire: Culture and the Nomadism of Representation, London, 2013 , p. 240.

37 Unwalla, p. Iо.

38 See Mary Price, A Strange, Confined Space, Stanford, I994, for a discussion of critics of the camera, including George Bernard Shaw, John Ruskin, and Baudelaire in relation to absence or loss in the photographic plane; Stieglitz's journal Camera Work (I9031907) compiled by Jonathan Green, Camera Work: A Critical Anthology, New York, I973, for references to debates around Pictorialism. In the context of South Asia, Bose's declaration of the camera's lack of heart (a loss of the quality of human emotion) echoes Charles Baudelaire's argument that the photograph existed in the absence of imagination. See Baudelaire quoted in Before Photography: Painting and the Invention of Photography, exh. cat., New York, pp. I I-3 I, p. 28.

39 Walter Benjamin, The Work of Art in an Age of Mechanical Reproduction, (trans.) J.A. Underwood, I936, repr. London, 2008, p. 6. 
40 See Jyoti Bhatt's conversation with KG Subramanyan in Lalit Kala Contemporary i 8: 'Personally, I do not see why mechanical devices should not be used by an artist [...] In fact all artists have used some tool or the other since the prehistoric times. Cameras, enlargers, and other mechanical devices are only more advanced types of tools. Why should he not use them if they serve this purpose?'

4I Moholy-Nagy, László, Painting Photography Film (trans.) Janet Seligman, I925, repr. Cambridge MA, I967: p. 5 I.

42 See Jorge Luis Borges, 'The Garden of Forking Paths' and 'Death and the Compass' in Labyrinths: Selected Stories and Other Writings, (trans.) Onís et al, New York, I964, pp. 3I-39, 79-88.

43 Richard Bartholomew, 'Seventh Members' Photographic Exhibition' in Thought, April 23, I960. Reproduced in Pablo Bartholomew (ed.), Richard Bartholomew: The Art Critic, NOIDA, 2012, pp. 499-500, p. 499. Bartholomew, a longstanding art critic, played an interesting mediating role in the New Delhi art network, at once negotiating institutional renown (as Secretary of the Lalit Kala Akademi from I977-85) and counter-institutional spaces (as a firm fixture in the social circles of the Bombay Progressives and the Baroda artists). 